\title{
Managed grazing and seedling shelters enhance oak regeneration on rangelands
}

\author{
Douglas D. McCreary \\ Melvin R. George \\ $\nabla$
}

Livestock grazing remains a common practice on California's hardwood rangelands. This can create problems for oak regeneration because grazing has been identified as one of the factors limiting the establishment of certain oak species. Previous research, as well as recent studies at the UC Sierra Foothill Research and Extension Center, suggests that cattle will damage both planted and/or naturally occurring oaks, but damage varies by season with less during the winter when deciduous oaks do not have leaves. Damage is also influenced by the density and distribution of cattle stocking. Oaks taller than 6.5 feet seem relatively resistant to cattle damage in lightly to moderately grazed pastures, but smaller seedlings need protection.

$\mathrm{F}^{o}$ r nearly a century there has been concern that several of California's 20 native oak species are not regenerating adequately (Jepson 1910). Such concern was partially responsible for the 1986 establishment of the Integrated Hardwood Range Management Program (IHRMP), a cooperative effort to promote oak woodland conservation by UC, the California Department of Forestry and Fire Protection, and the California Department of Fish and Game (Standiford and Bartolome 1997). Evidence indicating that there is an oak regeneration problem in California is based largely on the observed paucity of young seedlings and saplings in the understories of existing oak stands (Bartolome et al. 1987).

Describing the foothill oak woodlands in the Carmel Valley, White (1966) stated that "a prevailing characteristic ... is the lack of reproduction ... with very few seedlings." A survey of 15 blue oak

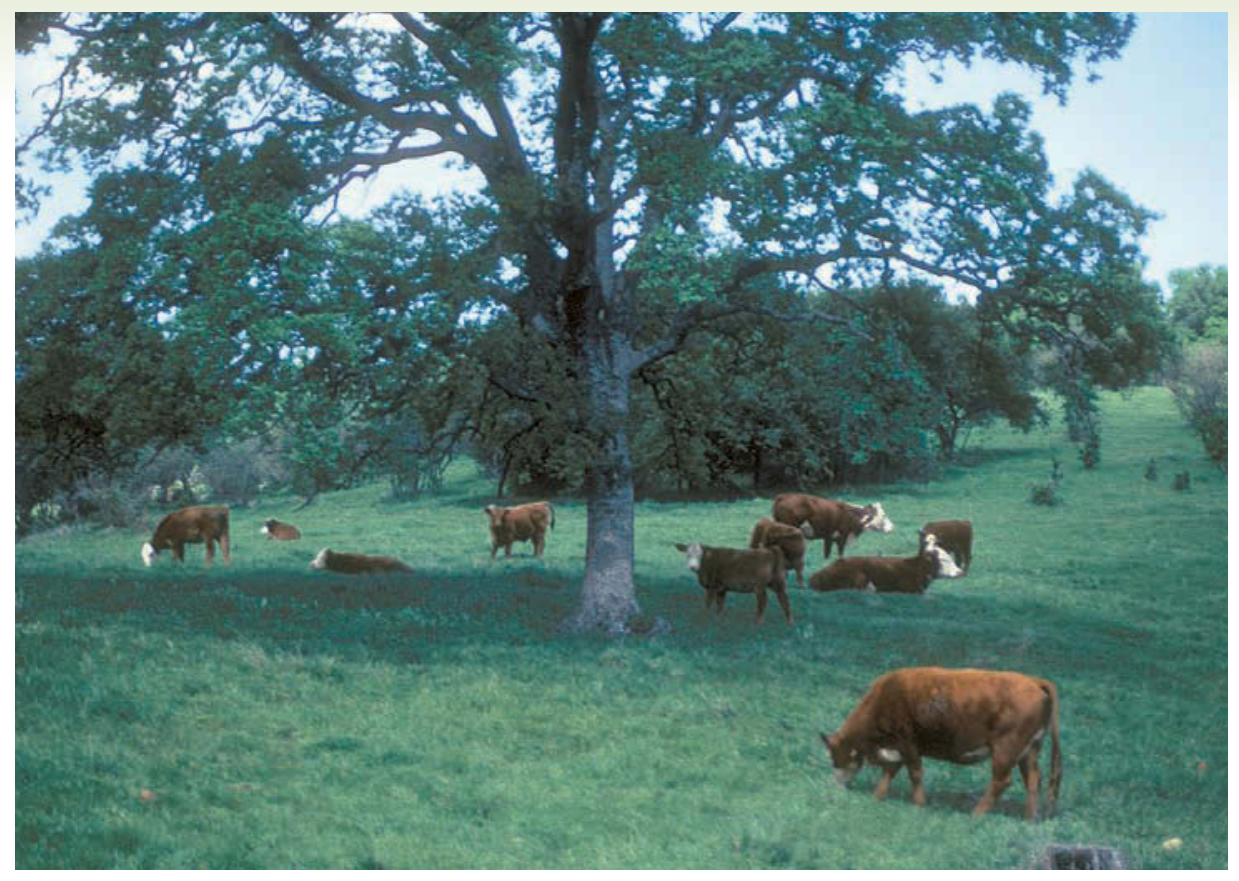

Most oak woodlands in California are privately owned and used primarily for grazing; however, livestock grazing is an important factor in the state's documented low rates of oak regeneration.

(Quercus douglasii) locations throughout the state showed that stands at 13 locations were losing oak density due to unreplaced mortality (Swiecki and Bernhardt 1998). The oak species having the most difficulty regenerating are members of the white oak subgenera of Quercus, including blue oak, valley oak (Q. lobata) and Engelmann oak (Q. engelmannii) (Muick and Bartolome 1987; Bolsinger 1988). Blue and valley oak are endemic to the state, while Engelmann oak extends into Baja California; however, the latter species actually has a far narrower distribution range than the other two (Griffin and Critchfield 1972).

During the last 2 decades, research has focused both on understanding the major factors contributing to oak regeneration failures and developing strategies to overcome these obstacles, including: how site and management factors affect oak regeneration; how acorns should be collected, stored and handled; how to propagate seedlings; and the best techniques for planting, protecting and maintaining seedlings in the field (McCreary 2001). The need to maintain and sustainably manage oak woodlands is important because these areas provide a wide range of societal benefits including aesthetics, recreational opportunities, watershed protection and wildlife habitat. Trees also provide shade for livestock and help enrich the soil through nutrient cycling. It is therefore not surprising that range managers are interested in obtaining information about raising livestock and oaks simultaneously.

\section{The role of livestock grazing}

Livestock grazing is a principal factor in poor oak regeneration in California. In the late 1980s, Lang (1988) surveyed hardwood-rangeland resource professionals and nearly $60 \%$ cited cattle herbivory as significantly limiting oak recruitment. One reason grazing and poor oak regeneration are believed to be connected is that the observed decline in regeneration roughly coincided with the widespread introduction and spread of livestock into the state during the Mission Period in the late 18th and early 19th centuries (Pavlik 1991). Both cattle and sheep eat oak seedlings, acorns and foliage, as evidenced by distinct browse lines on trees within grazed areas. While 


\section{The question of how cattle and oaks can be raised together is important because more than $80 \%$ of California oak woodlands are privately owned, with much of this land in livestock production.}

Range did not result in an increase in oaks (Duncan and Clawson 1980).

Bartolome, McLaran et al. (2002) examined the impacts of grazing on oakseedling establishment over 14 years and found that protected (ungrazed) seedlings grew significantly more than unprotected ones. They concluded that browsing pressures probably played an important role in suppressing height growth, although this likely would not have been sufficient to prevent regeneration at one of the two sites studied. These studies make it clear that even if oak seedlings are browsed, they can survive for years if not decades. Griffin (1971) observed oaks at the Hastings Reservation that remained stunted for at least 25 years before becoming large enough to escape deer browsing.

The UC Sierra Foothill Research and Extension Center in Yuba County supports a large herd of research cattle, which has helped scientists to study methods for improving oak regeneration in the presence of grazing.

oak foliage may not be preferred browse and blue oak foliage has been rated as poor forage for cattle (Sampson and Jesperson 1963), cattle did browse oaks at the San Joaquin Experimental Range and seemed to prefer blue oak foliage to that of interior live oak (Q. wislizenni) (Duncan and Clawson 1980).

Cattle have also been linked to poor oak regeneration by comparing grazed and ungrazed plots. Blue oak saplings were eight to nine times more likely to occur in nongrazed than grazed plots (Swiecki et al. 1997). Heavy grazing - especially over many years - can also indirectly affect oak recruitment because it increases vegetative density and soil compaction, and reduces organic matter, all of which can make it more difficult for oak roots to penetrate downward (Welker and Menke 1987). This study also reported that more moisture was available to the oak seedlings in the ungrazed site, presumably because there was more litter as well as lower plant densities than in the grazed site. However, protection from grazing and fire at the San Joaquin Experimental
However, in grazed settings some seedBernhardt and Swiecki (1997) reported extremely high mortality, especially for seedlings from acorns that were planted without protective cages. They also monitored 20 volunteer or natural valley-oak seedlings for 6 years and reported that two died, apparently due to grazing and trampling by cattle.

\section{Other factors affect regeneration}

Protecting small seedlings from cattle is one way to enhance regeneration.

Protected seedlings may even do better in some grazed sites than in ungrazed sites. Bernhardt and Swiecki (1997) reported that at two of three Northern California sites evaluated, the survival and growth of seedlings in protective cages were significantly greater in grazed than in ungrazed pastures, apparently due to reduced competition from herbaceous vegetation.

In a statewide oak-regeneration assessment, Muick and Bartolome (1986) reported that the presence or absence of livestock was not sufficient to explain the pattern of oak regeneration. Moreover, Griffin (1973) stated that “experiences in nongrazing areas, such as the UC Hastings Natural History Reservation in Carmel Valley, suggest that even without cows, sapling valley lings are obviously killed by livestock. oaks may be scarce." In the Hastings study, deer and gophers had significant impacts on oak regeneration, and Griffin reported that "a high deer population can devour most of the acorns and keep the few successful seedlings chewed down to nubbins."

Another factor that has been suggested as limiting natural oak regeneration in California is competition from introduced annual plants in the understory (Welker and Menke 1987). According to this theory, plants such as wild oats (Avena fatua), ripgut brome (Bromus diandrus) and Italian rye (Lolium multiflorum) utilize moisture differently than perennials, making it more difficult for oaks to become established in the spring.

Fire may also play a role. Due to fire suppression activities for much of the 20th century, the frequency of fires has been decreased on many hardwood rangelands, and fuels have accumulated in the understory. This fuel buildup may have created conditions unfavorable for oak recruitment by forming a thick layer from which it is difficult for seedlings to grow (Mensing 1992). However, neither prescribed burning (Allen-Diaz and Bartolome 1992) nor wildfire (Swiecki and Bernhardt 2002) have been found to positively affect oak recruitment.

Clearly there is no simple explanation for what is causing poor oak regeneration statewide. Multiple factors are involved, and those limiting recruitment at one site may be different at another. Competition from ground vegetation, herbivory by a variety of animals, environmental conditions, past management history and even landscape characteristics (Carmel and Flather 2004) likely contribute to the oak regeneration patterns in California today.

\section{Oak-cattle research at SFREC}

The UC Sierra Foothill Research and Extension Center (SFREC) is a 5,700-acre field station in the low-elevation Sierra Nevada foothills of Yuba County, which supports a large research cattle herd. It also provides land and facilities for natural resources research, part of which has been aimed at developing practical, 


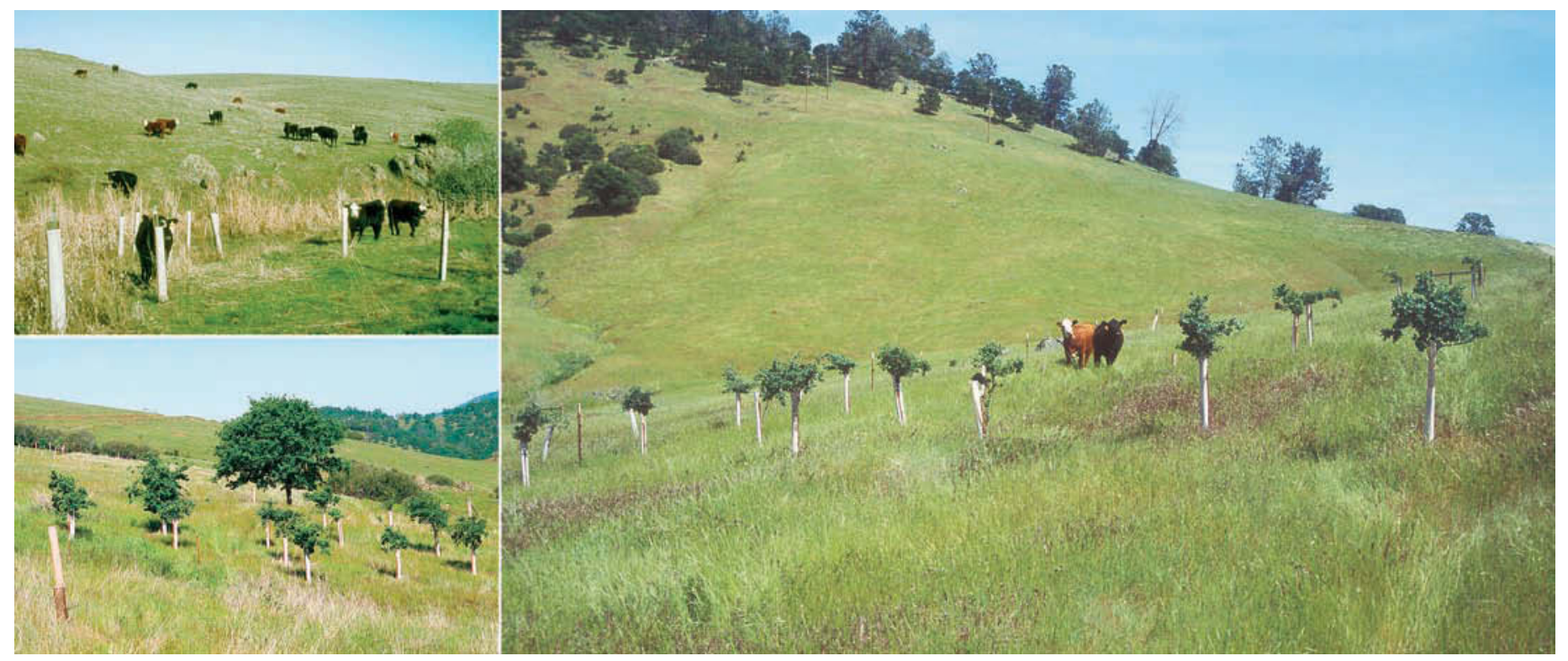

Tree shelters have proved effective in preventing cattle from trampling and grazing on oak seedlings. By the time oaks reach about 6.5 feet, they are generally able to withstand cattle damage in little- to moderately grazed pastures.

low-cost procedures for restoring oaks. Several of these studies have been conducted in areas grazed by cattle, with the objective of identifying how oaks can be established in grazed pastures without removing these lands from livestock production. The question of how cattle and oaks can be raised together is important because more than $80 \%$ of California oak woodlands are privately owned (Ewing et al. 1988), with much of this land in livestock production.

Grazing season. In 1989, Lillian Hall, a UC Davis graduate student, initiated an experiment at SFREC to evaluate how planted oak seedlings fare in fields accessed by cattle (Hall et al. 1992). She planted 1-year-old blue oak seedlings in pastures grazed by cattle at different stock densities (animals per unit area), and included a control where cattle were excluded. Although this study was limited in that the grazing plots were small and the grazing treatments were only carried out for a single year, some findings warrant noting. Damage to seedlings was significantly less in the winter and fall, when they did not have foliage and were apparently less appetizing to the cattle. Cattle did not seem to seek out or prefer young oaks, but in the spring they browsed the oak seedlings while grazing. She observed heavy damage to oak seedlings in the summer at all cattle densities. This may be because the young oaks were often the only green vegetation in the grazed pastures, and therefore more attractive than the dry annual grasses. Within each season, total oak-seedling damage also increased with increasing stock density.

Riparian restoration. In 1994, a study was initiated at SFREC to evaluate alternative practices for restoring woody plants along a perennial stream cleared in the late 1960s. Initially, few trees or shrubs were adjacent to the stream, and the predominant vegetation included broadleaved cattail (Typha latifolia), rushes (Juncus spp.) and sedges (Carex spp.). This study evaluated three methods for restoring woody plants along a 2,000-foot section: (1) fencing that excluded cattle but still gave deer access, (2) tree shelters to protect individual plants, and (3) a control consisting of planting but no protection. Tree shelters are rigid, translucent, double-walled plastic tubes placed over individual seedlings, protecting them from animals such as deer and cattle. The ones used in this study were 4 feet tall, and from about 3 inches to 5 inches in diameter (they are available in a variety of sizes). In grazed pastures, it is critical that these shelters be secured with heavy metal fence posts so that they do not bend over or break when cattle rub against them. These shelters also stimulate shoot growth of seedlings inside the tubes since they create a very favorable growing environment (McCreary and Tecklin 2001).

Each of the two protection treatments was replicated five times along 100-foot stretches of the stream, and in each rep- lication 70 total seedlings and cuttings were planted, including Fremont cottonwood (Populus fremontii), Arroyo willow (Salix lasiolepis), narrow-leaved willow (S. exigua), blue oak, valley oak and interior live oak. During each year of the study, cattle grazed the area where the plantings were located. Generally 30 to 60 head were placed for a 3- to 6-week period in the 130-acre pasture that surrounded and enclosed the study area. All plantings were evaluated annually for 4 years, and each plant was assessed for survival and year-end height.

The results of this study indicate that protecting individual seedlings with tree shelters was required for successful restoration of the oaks (McCreary 1999). After 4 years, average survival in tree shelters for all oak species combined was $58 \%$, while seedlings in fenced plots had only 5\% survival and unprotected seedlings in control plots had less than $1 \%$ survival. However, oak seedlings that did survive in tree shelters grew quite vigorously, with an average height of nearly 6.5 feet after 4 years.

Ungrazed and grazed plots. In 1997, a 4-acre blue oak planting that had been established at SFREC beginning in 1990 (Tecklin et al. 1997) was divided in two. Half of the six plots remained ungrazed while the other half were exposed to limited grazing for approximately 5 weeks per year (two cows for 2 to 3 weeks in both the fall and spring). The blue oak seedlings in the study area varied greatly in size because they had 


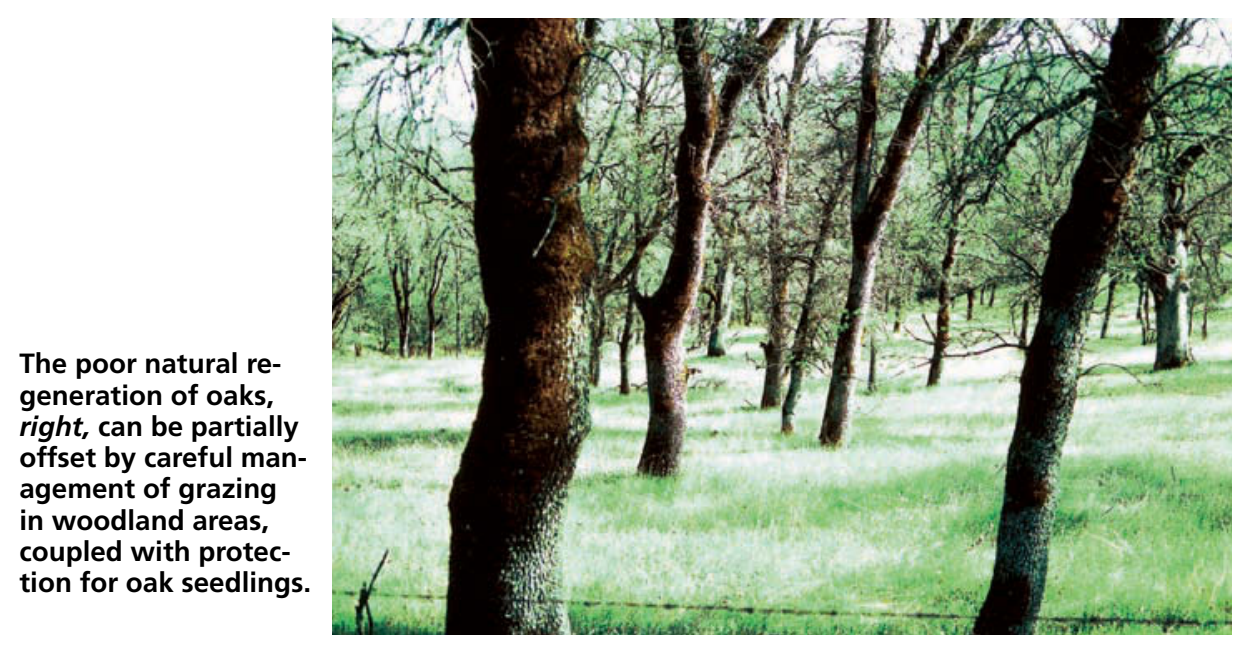

been established in different years and some were protected with tree shelters while others were not. As a result, the oaks ranged from a few inches tall - usually resprouts after seedlings had their bark stripped off near their bases by voles (Microtus californicus) - to healthy, robust saplings that had grown above the tops of the 4-foot tree shelters.

After 3 years, oaks inside the grazed plots were compared to those outside (Tecklin et al. 2002). Grazing did not result in any increased mortality, but there were differences in seedling condition. Unprotected seedlings in ungrazed plots had significantly more vole damage than those in grazed plots (52\% vs. 0\%). The ungrazed plots had a large increase in dead thatch, which is ideal habitat for voles and apparently resulted in higher populations and more bark stripping and girdling of oak seedlings.

For the oaks protected with tree shelters, however, the results were almost the opposite. There was evidence of far greater animal damage in the grazed plots — in this case by cattle - while there was virtually no animal damage to the oaks inside tree shelters in the ungrazed plots. In the grazed plots shoots above the tops of the 4-foot shelters were clipped, resulting in noticeably sparser crowns. Some of the shelters were also partially bent over from cattle rubbing (though all were secured with heavy metal fence posts), but no seedlings were killed. There were also differences in height and basal diameter growth between sheltered plants in the grazed and ungrazed plots, with those in grazed plots growing less. However, these differences were relatively small and browsed seedlings were not seriously damaged.

Oak size. A study to evaluate how cattle affect a range of sizes of oaks was initiated at SFREC in 2003. This study used a blue oak planting established between 1988 and 1990 by Ted Adams (Adams 1995), a UC Davis wildland specialist. Adams had established several hundred oaks inside a half-acre plot, fenced to exclude both deer and cattle. When our study began there were 144 living seedlings and saplings ranging from 17 inches to 14 feet high. This plot was within a 100-acre pasture that was subsequently grazed for 6 weeks each year by 50 cows and 49 calves as part of the Center's normal grazing operation. In 2003, half of Adams' plot was opened to cattle grazing. Prior to removing the fence around half of this plot, the researchers assessed each seedling in both halves for height, basal diameter, crown spread and crown height. From these latter two variables, crown volume was calculated (Karlik and McKay 2002).

After a full season of grazing, each oak was assessed for the same parameters. Seedlings and saplings that remained inside the fenced portion of the plot grew significantly taller than those exposed to cattle (an average of 8.7 inches vs. 3.1 inches for ungrazed and grazed, respectively). Although only one seedling was killed in the grazed portion, the cattle did severely damage a substantial number of the plants by browsing and rubbing.

However, damage from cattle varied greatly depending on the seedling's

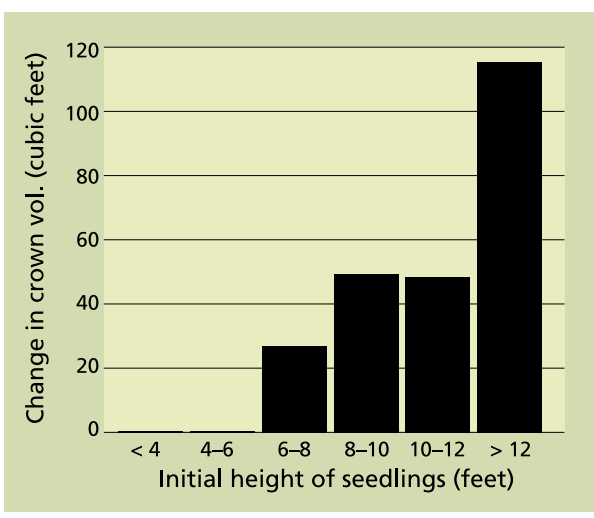

Fig. 1. Change in crown volume for seedlings of different heights after 1 year of grazing.

initial size. Oaks less than 6.5 feet tall were most likely to suffer damage. Of the 79 surviving oaks in the grazed plot, 11 lost more than 6 inches in height and these were all less than 6.5 feet tall when the study began. Furthermore, for the 46 oaks taller than 6.5 feet at the start, the average height gain during the 2003 growing season was 12 inches. In contrast, the 33 oaks less than 6.5 feet at the start of the study lost an average of 9 inches in height. The response was similar for basal diameter, with seedlings taller than 6.5 feet gaining an average of more than one-half inch in girth, and those shorter than 6.5 feet shrinking slightly (presumably because of clipping and rubbing by cattle). Crown volume also increased significantly for seedlings taller than 6.5 feet, while it diminished slightly for shorter seedlings (fig. 1).

Although this study has only been under way for the first of at least 3 planned years, initial results indicate that there is a threshold height - apparently near 6.5 feet - above which oaks may be large enough to withstand cattle damage in lightly to moderately grazed pastures and continue growing.

\section{Seedling protection recommended}

These trials, as well as other research, demonstrate that enhancing oak regeneration in areas grazed by livestock can be challenging since animals naturally browse seedlings. Without intervention, oak plantings in grazed areas often have little chance of significant growth or survival. However, the chances of success can be greatly increased by physically protecting seedlings and managing

- Continued on page 222 


\section{Grazing management guidelines}

$\mathrm{TO}$ reduce the risk of livestock damage to oak seedlings, grazing managers can control the grazing season and frequency, stocking rate and density, and practices that affect cattle distribution (George et al. 1996). Grazing leases usually include in-and-out dates (season) and number of head grazed (stocking rate and density), and many leases also dictate distribution practices such as the placement of salt or feed supplements. Under most conditions, the following practices can help reduce the risk of damage to oak seedlings by grazing livestock.

Grazing season. Rest (that is, do not graze) pastures to minimize damage in the summer, when oak seedlings and saplings are attractive to livestock because they remain green and are surrounded by lessattractive dry grass.

Grazing intensity. Moderate grazing removes about half of the annual forage production, preventing thatch buildup associated with vole damage to oak seedlings and saplings. In California's hardwood rangelands, moderate grazing is achieved in normal rainfall years with stocking rates of about 10 to 20 acres per cow per year, depending upon site productivity. Light grazing and no grazing results in thatch accumulation, while heavy grazing will likely increase the risk of seedling damage by livestock. Light grazing results from a lower stocking rate than moderate grazing, often about $50 \%$ of moderate grazing (20 to 40 acres or more per cow per year). Heavy grazing results from a stocking rate that is often $50 \%$ to $100 \%$ greater than moderate stocking rates (less than 10 acres per cow per year) (Bartolome, Frost et al. 2002; George et al. 1996).

Stock density. Avoid high stock densities during restoration projects in oak woodlands. Seedlings and saplings are at a greatly increased risk of damage when pastures are subdivided into many paddocks for intensive grazing regimens. Stock densities of less than one cow per acre are preferable to higher stock densities.

Cattle distribution. Planting oaks more than 0.5 mile from stock water and on slopes greater than $20 \%$ can reduce the risk of grazing impacts on oak seedlings. This is because cattle do not like to walk great distances from water and they prefer to graze on flat-togentle slopes. The time livestock spend near oak regeneration sites can also be reduced by placing attractants such as salt, supplements, rubbing posts and water as far away from the oaks as practical. In addition, knowledge of cattle's preferred resting sites, feeding sites and trail corridors can help in the selection of oak regeneration sites that are less vulnerable to browsing or trampling. Cattle follow a predictable daily path of grazing and rest. At sunrise they begin grazing at their night resting location and generally graze toward water. After grazing for about 4 hours, they rest until moving to water sometime between late morning to midafternoon. They will then rest again, often near the water source, preferring shade in the summer months. In midafternoon to early evening, they will have another grazing bout of approximately 4 hours before reaching a night resting site (Harris et al. 2002).

Protecting planted seedlings. Areas with planted oaks should be fenced until seedlings are at least 6.5 feet tall, or individual seedlings should be protected until they attain this height. Excellent protection in moderately grazed pastures can be achieved by placing 4-foot-tall tree shelters around young seedlings; such shelters cost about $\$ 3$ each and are difficult to reuse since they usually must be cut off. These devices not only protect seedlings from a variety of potentially damaging animals, including cattle, but also stimulate rapid aboveground growth.

Where livestock are present, shelters must be well secured to heavy metal fence posts to ensure that they remain upright and are not bent over from cattle rubbing. However, even this degree of protection may not be adequate in heavily grazed pastures since cattle in confined areas will often repeatedly rub against the shelters and posts, and can knock them over and damage the young seedlings. Oaks growing up and out of the tops of 4-foot tall shelters are also vulnerable to livestock clipping of the exposed shoots, but in lightly to moderately grazed pastures such damage appears to have limited long-term impact on seedling survival or growth. Where shelters are used, it is important to leave them in place for at least 2 years after the seedlings have grown up and out of the tops. If they are removed too soon the seedlings will be vulnerable to cattle damage since they will not be sturdy enough to withstand cattle rubbing and clipping.

Protecting natural seedlings. Another approach is to protect existing volunteer or natural seedlings. Such seedlings are often heavily browsed and have little chance of surviving without protection from cattle. Little research has been conducted on this, but Bernhardt and Swiecki (1997) reported that caged juvenile seedlings grew significantly more than uncaged controls in a grazed pasture. Tree shelters can therefore be used on naturally established seedlings to increase their chances of maturing into oak trees.

These practices can enhance the chances for regeneration success of native California oaks in areas grazed by livestock. But whatever steps are taken, it is important to monitor the results and alter practices as needed. We do not yet know what will and will not work in all situations, so it is vital to pay attention and modify procedures as needed.

For more information, go to: http:// danr.ucop.edu/ihrmp.

- D.D. McCreary and M.R. George 
the stock densities and grazing seasons. In addition, managing physical features such as salt blocks, supplements and water can influence cattle distribution and limit impacts to oak seedlings and saplings (see sidebar).

D.D. McCreary is Natural Resources Specialist, UC Sierra Foothill Research and Extension Center, Browns Valley; and M.R. George is Rangeland Management Specialist, Department of Agronomy and Range Science, UC Davis.

\section{References}

Adams TE. 1995. White oak regeneration techniques. UC Sierra Foothill Research and Extension Center Ann Rep 1994-1995. Browns Valley, CA. p 21-3.

Allen-Diaz BH, Bartolome JW. 1992. Survival of Quercus douglasii (Fagaceae) seedlings under the influence of fire and grazing. Madroño 39(1):47-53.

Bartolome JW, Frost WE, McDougald NK, Connor JM. 2002. California Guidelines for Residual Dry Matter (RDM) Management on Coastal and Foothill Annual Rangelands. Rangeland Monitoring Series, UC ANR Pub 8092, Oakland, CA. 8 p.

Bartolome JW, McClaran MP, Allen-Diaz $\mathrm{BH}$, et al. 2002. Effects of fire and burning on regeneration of blue oak. In: Standiford RB, McCreary DD, Purcell KL (tech. coords.). Proc Fifth Symp Oak Woodlands: Oaks in California's Changing Landscape, Oct. 22-5. 2001; San Diego, CA. USDA For Ser PSW Res Sta Gen Tech Rep PSW-184. p 281-6.

Bartolome JW, Muick PC, McClaran MP. 1987. Natural regeneration of California hardwoods. In: Plumb TR, Pillsbury NH (tech. coords.). Proc Symp Multiple-use Management of California's Hardwood Resource, Nov. 12-4, 1986; San Luis Obispo, CA. USDA For Ser PSW For and Range Exp Sta Gen Tech Rep PSW-100. p 26-31.

Bernhardt EA, Swiecki TJ. 1997. Effects of cultural inputs on survival and growth of direct seeded and naturally occurring valley oak seedlings on hardwood rangelands. In: Pillsbury NH, Verner J, Tietje WD (tech. coords.). Proc Symp Oak Woodlands: Ecology, Management and Urban Interface Issues, March 19-22, 1996; San Luis Obispo, CA. USDA For Ser PSW Res Sta Gen Tech Rep PSW160. p 301-11.

Bolsinger CL. 1988. The Hardwoods of California's Timberlands, Woodlands and Savannas. USDA For Ser PNW Res Sta Res Bull PNW-148. $148 \mathrm{p}$.

Carmel Y, Flather $\mathrm{CH}$. 2004. Comparing landscape scale vegetation dynamics following disturbance in climatically similar sites in California and the Mediterranean basin. Landscape Ecol 19(6):553-90.
Duncan DA, Clawson WJ. 1980. Livestock utilization of California's oak woodlands. In: Plumb TR (tech. coord.). Proc Symp Ecology, Management and Utilization of California Oaks, June 26-8, 1979; Claremont, CA. USDA For Ser SW For and Range Exp Sta Gen Tech Rep PSW-44. p 306-13.

Ewing RA, Tosta N, Tuazon R, et al. 1988. Growing Conflict Over Changing Uses. Calif Dept For Fire Prot. Sacramento, CA: Anchor Pr. 348 p.

George MR, Frost WE, McDougald NK, et al. 1996. Livestock and grazing management. In: Standiford RB (tech. coord.). Guidelines for Managing California's Hardwood Rangelands. UC ANR Pub 3368. p 51-67.

Griffin JR. 1971.Oak regeneration in the upper Carmel Valley, California. Ecology 52(5):862-8.

Griffin JR. 1973. Valley oaks - the end of an era? Fremontia 1(1):5-9.

Griffin JR, Critchfield WB. 1972. The Distribution of Forest Trees in California. USDA For Ser PSW For and Range Exp Sta Res Pap PSW-82. $114 \mathrm{p}$.

Hall LM, George MR, McCreary DD, Adams TE. 1992. Effects of cattle grazing on blue oak seedling damage and survival. J Range Mgmt 45(5):503-6.

Harris NR, Johnson DE, George MR, McDougald NK. 2002. The effect of topography, vegetation and weather on cattle distribution at the San Joaquin Experimental Range, California. In: Standiford RB, McCreary DD, Purcell KL (tech. coords.). Proc Fifth Symp Oak Woodlands: Oaks in California's Changing Landscape, Oct. 22-5. 2001; San Diego, CA. USDA For Ser PSW Res Sta Gen Tech Rep PSW-184. p 53-63.

Jepson WL. 1910. The Silva of California. University of California memoirs. Berkeley, CA $480 \mathrm{p}$.

Karlik JF, McKay AH. 2002. Leaf area index, leaf mass density, and allometric relationships derived from harvest of blue oaks in California oak savanna. In: Standiford RB, McCreary DD, Purcell KL (tech. coords.). Proc Fifth Symp Oak Woodlands: Oaks in California's Changing Landscape, Oct. 22-5. 2001; San Diego, CA. USDA For Ser PSW Res Sta Gen Tech Rep PSW-184. p 719-29.

Lang JF. 1988. Oak Regeneration Assessment - A Problem Analysis. Prepared for the California Forestry and Fire Protection Program Forest and Rangeland Resources Assessment Program. Sacramento, CA. 85 p.

McCreary DD. 1999. Restoration of a grazed riparian area. In: Rose $R$, Haase DL (eds.). Proc Symp Native Plants: Propagating and Planting, Dec. 9-10, 1998; Corvallis, OR. Oregon State University Nursery Technology Cooperative. p 86-91.

McCreary DD. 2001. Regenerating Rangeland Oaks in California. UC ANR Pub 21601, Oakland, CA. 62 p.

McCreary DD, Tecklin J. 2001. The effects of different-sized treeshelters on blue oak growth. West J App For 16(4):153-8.

Mensing SA. 1992. The impact of European settlement on blue oak regeneration and recruitment in the Tehachapi Mountains, California. Madroño 39(1):36-46.
Muick PC, Bartolome JW. 1986. Oak regeneration on California's hardwood rangelands. In: Trans., West Sec of the Wildlife Soc 22:121-5.

Muick PC, Bartolome JW. 1987. Factors associated with oak regeneration in California. In: Plumb TR, Pillsbury NH (tech. coords.). Proc Symp Multiple-use Management of California's Hardwood Resource, Nov. 12-4, 1986; San Luis Obispo, CA. USDA For Ser PSW For and Range Exp Sta Gen Tech Rep PSW100. p 86-91.

Pavlik BM, Muick PC, Johnson S, Popper M. 1991. Oaks of California. Los Olivos, CA: Cachuma Pr. $184 \mathrm{p}$.

Sampson AW, Jesperson BS. 1963. California Range Brushlands and Browse Plants. UC ANR Manual 33. $162 \mathrm{p}$.

Standiford RB, Bartolome JW. 1997. The Integrated Hardwood Range Management Program: Education and research as a conservation strategy. In: Pillsbury NH, Verner J, Tietje WD (tech. coords.). Proc Symp Oak Woodlands: Ecology, Management and Urban Interface Issues, March 19-22, 1996; San Luis Obispo, CA. USDA For Ser PSW Res Sta Gen Tech Rep PSW-160. p 569-81.

Swiecki TJ, Bernhardt E. 1998. Understanding blue oak regeneration. Fremontia 26(1):19-26.

Swiecki TJ, Bernhardt E. 2002. Effects of fire on naturally occurring blue oak (Quercus douglasii) saplings. In: Standiford RB, McCreary DD, Purcell KL (tech. coords.). Proc Fifth Symp Oak Woodlands: Oaks in California's Changing Landscape, Oct. 22-5. 2001; San Diego, CA. USDA For Ser PSW Res Sta Gen Tech Rep PSW-184. p 251-9.

Swiecki TJ, Bernhardt EA, Drake C. 1997. Factors affecting blue oak sapling recruitment and regeneration. In: Pillsbury $\mathrm{NH}$, Verner J, Tietje WD (tech coords.). Proc Symp Oak Woodlands: Ecology, Management and Urban Interface Issues, March 19-22, 1996; San Luis Obispo, CA. USDA For Ser PSW Res Sta Gen Tech Rep PSW-160. p 157-68.

Tecklin J, Connor JM, McCreary DD. 1997. Rehabilitation of a blue oak restoration project. In: Pillsbury NH, Verner J, Tietje WD (tech. coords.). Proc Symp Oak Woodlands: Ecology, Management and Urban Interface Issues, March 19-22, 1996; San Luis Obispo, CA. USDA For Ser PSW Res Sta Gen Tech Rep PSW-160. p 267-73.

Tecklin J, Connor JM, McCreary DD. 2002. Rehabilitation of an oak planting project on cleared rangeland using treeshelters and grazing: A ten-year saga (poster abstract). In: Standiford RB, McCreary DD, Purcell KL (tech. coords.). Proc Fifth Symp Oak Woodlands:

Oaks in California's Changing Landscape, Oct. 22-5. 2001; San Diego, CA. USDA For Ser PSW Res Sta Gen Tech Rep PSW-184. p 839.

Welker JM, Menke JW. 1987. Quercus douglasii seedling water relations in mesic and grazing-induced xeric environments. Proc Int Conf Measurement of Soil and Plant Water Status, July 6-10, 1987; Utah State Univ, Logan, UT. Vol. 2, Plants. p 229-34.

White KL. 1966. Structure and composition of foothill woodland in central-coastal California. Ecology 47(2):229-37. 